\title{
OSALLISTUMISEN JA OPISKELUIN VAIKUTTAVUUS KANSALAIS- JA TYÖVÄENOPISTOISSA
}

\begin{abstract}
"Pyrkimys kehittää kokonaispersoonallisuutta sekä edistää kulttuuri- ja yhteiskuntaelämää ei ole sanahelinää, vaan todellisuutta aikuisten opiskeluun osallistujien elämänpyrkimyksissä", toteavat artikkelin kirjoittajat kansalais- ja työväenopistoissa opiskelevista aikuisista.
\end{abstract}

Kirjoittajat ovat selvittäneet entisen kouluhallituksen kokeilu- ja tutkimustoimiston toimeksiannosta, millaiset tavoitteet kansalais- ja työväenopistojen toimintaan osallistuvilla aikuisilla on, kuinka opistojen tarjonta vastaa heidän mielestään heidän odotuksiaan ja kuinka vaikuttavana he kokevat osallistumisensa ja opiskelunsa.

Kansalais- ja työväenopistot elävät muutosten aikaa: opistolaki uudistuu, valtionapusäädökset muuttuvat. Myös opetushallinnon uudistuminen sekä vapaakuntakokeilut vaikutta. vat opistojen toiminnan edellytyksiin. Muutokset ovat toisaalta uhka, toisaalta mahdollisuus.

Suomalaista koulutuspolitiikkaa linjataan jatkuvan koulutuksen periaatteen mukaisesti. Idea opiskelun ja oppimisen mahdollistamisesta koko elämän ajan edellyttää, että muodollinen koulutusjärjestelmä — siis myös aikuiskoulutus - on sisällöltään ja rakenteeltaan avoin ja joustava. Nimenomaan aikuiskoulutukselta odotetaan nyt yhä enemmän. Ammatillinen aikuiskoulutus on saanut aina vuoden 1978 valtioneuvoston periaatepäätök. sestä lähtien erityistä huomiota osakseen. Mutta perinteisemmällä aikuiskoulutuksella, vapaalla sivistystyöllä, on myös tärkeä tehtävä elinikäisen oppimisen tukemisessa.

Joitakin vuosia sitten epäiltiin vapaan sivistystyön ja nimenomaan opistoliikkeen jääneen pahasti jälkeen ympäröivän yhteiskun- nan kehityksestä ja ihmisten todellisista sivistyksellisistä tarpeista. Opistojen sanottiin jämähtäneen veneveistämöiksi ja mattokutomoiksi; ainoana muutoksena pidettiin muuntumista musiikkioppilaitoksiksi. Yleisesti on puhuttu myös siitä, että hyötytavoitteet ovat ylikorostuneet opiskelussa.

Entisen kouluhallituksen kokeilu- ja tutkimustoimiston toimeksiannosta kirjoittajaryhmä otti selvittääkseen, millaiset tavoitteet tänä päivänä kansalais- ja työväenopistotoimintaan osallistuvilla aikuisilla on ja kuinka hyvin heidän mielestään opistojen tarjonta vastaa heidän odotuksiaan sekä kuinka vaikuttavana he kokevat osallistumisensa ja opiskelunsa.

\section{Aikuiskoulutukseen osallistumisen tutkimisesta}

Yksi vanhimmista osallistumistavoitteiden jaotteluista on peräisin saksalaiselta sosiologi Leopold von Wieseniltä. von Wiese jakoi va. paisiin ryhmäopintoihin osallistujat neljään seuraavaan ryhmään: "1. Pohjaltaan kiinnostu- 
mattomat, uteliaisuudesta tai tilapäisestä ulkoisesta sysäyksestä tulleet. 2. Ne, jotka panee liikkeelle oppositiohenki kirkkoa, koulua ja esivaltaa vastaan. 3. Sosiaalisen kohoamisen keinoja etsivät. 4. Ne, jotka hakevat sivistystä ja tietoa rakkaudesta asiaan ja persoonallisen kehittymispyrkimyksen vuoksi." (Alanen 1969, 11.)

Osallistumistavoitteita ja opiskelumotiiveja on aikuiskoulutuksen alalla tutkittu runsaasti. Yhtenäistä, osallistumista selittävää teoriaa ei silti ole. Tutkimuksissa etsitään yleensä faktorianalyysin keinoin osallistumisen perusulottuvuuksia.

Lehtonen ja Tuomisto kehittelivät teoreettista osallistumisen perusmallia parikymmentä vuotta sitten. Heidän määritelmänsä mukaan osallistumista on organisoitujen aikuisopintojen harjoittaminen. Kun aikuinen päättää käyttää hyväkseen aikuiskoulutuspalveluja, on edessä asteittain etenevä prosessi. Sen eri vaiheissa osallistumiseen vaikuttavat yksilön odotukset sekä erilaiset yhteiskunta-, yhteisö- ja yksilötason tekijät. Osallistumisprosessin viriäminen edellyttää tietoa aikuiskoulutuspalveluista, kiinnostusta koulutusta kohtaan ja lisätiedon etsimistä tietyistä kursseista. Osallistumispäätös edellyttää, että tarjolla olevien koulutuspalvelujen ja osallistumishalukkuuden välillä on vastaavuutta, ts. opiskelija arvioi osallistumisen etuja ja haittoja. Usein ensimmäiset osallistumiskerrat ovat kokeilua ja sen punnitsemista, vastaako koulutus omia tavoitteita. Osallistumispäätös tehdään vasta sitten. (Lehtonen $\mathcal{E}$ Tuomisto 1972, 24 - 26; Bock 1980, 124 - 130.)

Osallistumistavoitteiden luokitteluista tunnetuin lienee Houlen typologia oppimis-, päämäärä- ja toimintahakuisista opiskelijoista. Sitä hyvin lähellä on Alasen (1985) luokittelu, jossa tavoitteet jaetaan oppimistavoitteisiin ja viihteellisiin tavoitteisiin. Ensin mainittuihin sisältyvät kehittymisen ja käytännöllisen hyödyn motiivit ja jälkimmäisiin viihtyisän yhdessäolon ja arkirutiineista irtautumisen motiivit. Ulkomainen kirjallisuus näyttää useimmiten viittaavan Boshierin luokitteluun ja hänen kehittelemäänsä osallistumismittariin (Education Participation Scale; ks. esimerkiksi Boshier 1982 ja Boshier E Collins 1985).

\section{Vaikuttavuuden ja toiminta-ajatuksen toteutumisen arvioiminen}

Vaikuttavuus tarkoittaa yleisessä merkityksessään asetettujen tavoitteiden saavuttamista.
Arvioinnissa olisi luonnollisestikin otettava huomioon eri tahojen näkemykset tavoitteista ja niiden saavuttamisesta. Joskus näitä määrittäjätahoja on kuitenkin rajattava. Tärkeimpiä määrittäjiä ovat koulutettavat itse: tällöin voidaan puhua koetusta vaikuttavuudesta. Sen lähikäsitteitä ovat opiskelun mielekkyys ja merkityksellisyys.

Aikuisopiskelijan käyttämät koulutuksen arviointikriteerit perustuvat hänen elämäntilanteeseensa ja -kokemukseensa. Koulutus ja opiskelu on aikuiselle merkityksellistä ja sitä kautta mielekästä, kun hän kokee opiskelta. van asian tärkeäksi oman elämän- ja työtilanteensa kannalta. Lisäksi aikuisella täytyy olla omakohtainen halu opiskella ja hänen tiedollisen rakenteensa on oltava vastaanottavainen opiskeltavalle ainekselle. (Vaherva 1983, 127 - 129.)

Vapaata sivistystyötä arvioitaessa on otettava huomioon alan olemus ja toiminta-ajatus. - Z. Castrén määritteli vuonna 1929 yhden miehen komiteassaan vapaan sivistystyön perusajatuksen tavalla, joka tuntuu kovin tutulta - onhan se näihin päiviin saakka ohjannut myös opistoliikkeen toimintaa:

"Vapaaksi kansansivistystyöksi sanotaan kaikkea sitä moninaista tointa, jonka tarkoituksena on saada hereille ja edistää aikuisten vapaita itsekasvatuspyrkimyksiä, s.o. heidän pyrkimyksiänsä sekä tietojensa sy. ventämiseen ja laajentamiseen että tunne. elämänsä ja käytöstapansa jalostamiseen, jotta he täydellisemmin kehittyisivät sivisty. neiksi ihmisiksi ja vastuukykyisiksi yhteis. kunnan jäseniksi niissä elämänoloissa ja tehtävissä, jotka he tuntevat omikseen".

Vapaan sivistystyön toiminta-ajatus perustuu sananmukaisesti vapaavalintaisuuteen, ja tavoitteet ovat sen mukaan yleisiä ja monitahoisia. Itse asiassa tavoitteita on niin monta kuin on opiskelijoitakin, ja tässä mielessä juuri koetulla vaikuttavuudella on keskeinen sija arvioinnissa.

\section{Tämänhetkistä tilannetta tutkimassa}

Tässä nyt raportoitavan tutkimuksen ensim. mäisessä ongelmassa esitettiin kysymys, millaisia ovat kansalais- ja työväenopistojen opiskelijoiden osallistumistavoitteet. Toisessa ongelmassa kysyttiin, millaisiksi opiskelijat kokevat opiskelunsa vaikuttavuuden, ja kolmannessa haluttiin vastaus siihen, miten opiskelijat 
arvioivat kansalais- ja työväenopistojen toiminta-ajatuksen toteutuvan.

Vastaukset kysymyksiin haluttiin mahdollisimman edustavalta joukolta aikuisopiskelijoita ja siksi päädyttiin strukturoituun postikyselyyn. Lomakkeen pohjaksi oli aiemmin tehty proseminaarityönä peruskartoitus osallistumis tavoitteista ja opiskelun koetusta merkityksestä (Hanhisalo E Kauppila, Jyväskylän yliopisto 1989). Varsinaisen empiirisen kyselytutkimuksen teki Sanna Virolainen kasvatustieteen pro gradu -työnään (Jyväskylän yliopisto 1991) Vahervan ja Rengon ohjauksessa.

Otokseen tuli 40 opintopiiriä kahdeksasta opistosta, jotka oli valittu kaksivaiheisella otantamenetelmällä. Opintopiirit vastasivat hyvin opistojen tyypillisimpiä aineita ja niiden osallistujajoukko oli hyvin heterogeeninen. Aineisto koottiin kevättalvella 1990. Hyväksytysti täytettyjä lomakkeita oli analyyseissä mukana 371 kappaletta. Vastaajista 70 prosenttia oli naisia ja 30 prosenttia miehiä.

\section{Mitä osallistujat tavoittelevat?}

Myös tässä tutkimuksessa etsittiin osallistumisen perusdimensioita ja siksi osallistumistavoitteet faktoroitiin ja tehtiin oblimin-rotatointi. Tulokseksi saatiin neljä faktoria, jotka selittivät 60.2 prosenttia muuttujien kokonaisvaihtelusta.

I Sosiaalisten kontaktien ja arjesta irtautumisen faktori. Tätä ulottuvuutta luonnehtivat halu saada uusia ystäviä, lisätä itsen ja muiden tuntemusta, päästä vuorovaikutukseen toisten ihmisten kanssa ja irti tavanomaisista ympy. röistä.

Il faktorilla korkeita latauksia saivat muuttujat, jotka kuvaavat työssä ja muissa opinnoissa etenemisen ja yhteiskunnallisen vaikuttamisen päämääriä. Faktoria virittävät muuttujat liittyivät käytännöllisiin ja ammatillisiin tavoitteisiin. Se nimitettiin käytännöllis-ammatilliseksi faktoriksi.

III faktorilla yleissivistävän tietämyksen ja maailmankuvan laajentamisen muuttujat saivat korkeita latauksia. Ulottuvuus olikin helppo nimetä yleissivistyksen kohottamisen faktoriksi.

IV itsensä kehittämisen faktori. Faktori liittyy selkeästi itsensä kehittämiseen uutta opiskelemalla ja vanhoja tietoja täydentämällä.
Suurimmat painokertoimet saaneita muuttujia olivat halu käyttää vapaa-aikaa itsensä kehittämiseen, ylläpitää ja täydentää aiempia tietoja ja taitoja sekä osoittaa, että pystyy oppimaan uutta.

Itsensä kehittämistä ja opiskelun harrastusluonteisuutta korostavat osallistumistavoitteet näyttivät olevan yleisimpiä osallistumisen syitä kansalais- ja työväenopistoissa opiskelevilla aikuisilla - eli aivan kuten opistojen toimintaajatuksessa oletetaankin. Välineelliset, työhön ja muuhun opiskeluun liittyvät tavoitteet olivat ensisijaisia syitä vain osalla opiskelijoista. Naisopiskelijat korostivat opiskelun sosiaalista merkitystä useammin kuin miehet.

Opintopiirien välillä löytyi luontevia eroja opiskelutavoitteissa: kielipiireissä opiskelevat korostivat oppimis- ja yleissivistyskeskeisiä motiiveja, kun taas yhteiskunnallisten aineiden piireissä opiskelijat olivat selvästi päämääräkeskeisempiä ja taito- ja taideaineita puolestaan opiskeltiin pääasiassa sosiaalisten kontaktien ja itsensä kehittämisen vuoksi.

Opiskelijoiden elämänvaiheilla tai -tapahtumilla ei näyttänyt olevan merkittävää yhteyttä tavoitteisiin eikä osallistumiseen.

\section{Kuinka vaikuttavana opiskelu koetaan?}

Opisto-opiskelu oli pääasiassa koettu hyvin myönteisesti. Opiskelun tiedolliset vaikutukset sekä vaikutukset omaan ajankäyttöön ja vapaa-aikaan arvioitiin suuriksi. Noin 70 prosenttia vastaajista katsoi uuden tiedon hankkimisen sinänsä olleen tärkeää ja lähes puolet arvioi voineensa täydentää aikaisemmin oppimiaan tietoja ja taitoja. Vaihtelua elämään ja mielekästä tekemistä vapaa-aikaan sai yli puolet vastaajista. Noin puolet vastaajista arvioi, että kiinnostus yleensä opiskelua kohtaan oli lisääntynyt.

Suuri osa katsoi myös saaneensa uusia ystäviä tai tutustuneensa uusiin ihmisiin opiskelun yhteydessä. Opisto-opiskelun ei sen sijaan katsottu juuri vaikuttaneen kulttuuriharrastuksiin, ammattiin, työelämässä etenemiseen tai muuhun opiskeluun osallistumiseen. Opiskelu ei näytä vaikuttaneen liioin yhdistystoimintaan osallistumiseen eikä kiinnostukseen yhteiskunnallisia kysymyksiä kohtaan.

Naisten ja miesten välillä oli selviä eroja vaikutusten kokemisessa. Naiset kokivat saaneensa opiskelusta enemmän kaikilla osallis- 
tumisen osa-alueilla; selvimmät erot olivat vapaa-ajan käytössä sekä yleissivistyksen kohoamisessa ja itseluottamuksen lisääntymisessä.

Tutkimuksessa selvitettiin myös, löytyykö opisto-opiskelun koetusta vaikuttavuudesta vastaavanlaista rakennetta kuin osallistumis. motiiveista. Analyysi tuotti nelifaktorisen mallin, joka selitti 58.5 prosenttia muuttujien vaihtelusta.

I faktori nimettiin osallistumisen lisääntymisen faktoriksi. Siinä painottuivat useat aktivoitumisen kasvua kuvaavat muuttujat. Myös osallistumisrohkeus ja itseluottamus lisääntyivät opiskelun seurauksena.

II faktoria virittivät elämän ja arjen sisällön paranemista kuvailevat muuttujat. Vaikutukset liittyivät omaan itseen ja omaan elämänpiiriin. Ulottovuus nimettiin elämän mielekkyyden paranemisen faktoriksi.

III faktorin sisältö on kaksijakoinen: toisaalta opiskelijat olivat kokeneet sosiaalisten kontaktiensa lisääntyneen ja toisaalta opiskelun nähtiin vaikuttaneen myös jossain määrin ammattitaidon kehittymiseen ja työelämässä etenemiseen. Faktori nimettiin sosiaalisten kontaktien ja ammattitaidon lisääntymisen faktoriksi.

IV faktorilla painottuivat yleissivistykseen ja uuden tiedon hankkimiseen liittyvät muuttujat, nimenomaan tiedon itseisarvoista merkitystä korostavat vaikutukset. Ulottuvuudelle annettiin nimeksi itsensä kehittämisen faktori.

Koettujen vaikutusten tarkastelu taustamuuttujittain osoitti, että naiset kokivat hyötyvänsä opisto-opiskelusta enemmän kuin miehet. Opiskelu näytti hyödyttävän enemmän niitä, joilla oli vähäisempi koulupohja, samoin kuin niitä, joiden ammatillinen koulutustaso oli vaatimattomampi. Kansalais- ja työväenopistoopiskelu näyttää siis paljolti vähentävän elämisen ja tekemisen rajoituksia ja lisäävän mahdollisuuksia - ainakin elämyksellisesti koettujen vaikutuksien pohjalta arvioiden.

Opiskelun koetut vaikutukset vastaavat opiskelijoiden opiskelulleen asettamia tavoitteita. Vain ne aikuiset, joilla ammatillinen hyöty oli ensisijaisena osallistumistavoitteena, kokivat pettymyksiä, mutta heilläkin opiskelun muut tiedolliset vaikutukset ja sosiaaliset kontaktit näyttävät korvanneen ammatillisemmat odotukset.

\section{Toteutuuko opistoliikkeen toiminta-ajatus?}

Opistoja koskevan lain määrittämän toiminta-ajatuksen pohjalta muodostettiin kysymysosioita, joilla kartoitettiin opiskelijoiden käsityksiä siitä, kuinka hyvin opistot toteuttavat toiminta-ajatustaan. Vuonna 1973 Lehtonen ja Tuomisto olivat tutkineet samaa asiaa 'Kansalaisopisto organisaationa' -tutkimuksessaan. Nyt oli mahdollista selvittää, olivatko käsitykset muuttuneet kuluneiden kahden vuosikymmenen aikana vertailemalla tutkimusten samansisältöisiin osioihin annettuja vastauksia. Nämä osiot koskivat sitä, miten hyvin opistot olivat täyttäneet seuraavat tehtävänsä:

1) vanhentuneiden tai puutteellisten kouluopintojen täydentäminen,

2) ammatissa tarvittavien tietojen ja taitojen kehittäminen,

3) yhteiskunnallisessa toiminnassa tarvittavien tietojen hankkiminen,

4) persoonallisuuden kehittäminen ja

5) yleissivistyksen kohottaminen.

Kuvion 1 keskiarvot osoittavat, mitä eroja/yhtäläisyyksiä on Lehtosen ja Tuomiston (1973) ja tämän tutkimuksen (1991) aineiston välillä.

Opiskelijoiden mielestä opistot toimivat keskimäärin tyydyttävästi keskeisillä toiminta-ajatuksen alueilla. Oleellisia mielipide-eroja ei 70- ja 90-lukujen vertailussa löydy. Ja lievät erot on helppo tulkita: yleinen koulutustaso on noussut ja peruskoulu(tus) pystyy aiempaa paremmin huolehtimaan sekä yhteiskunnallisessa toiminnassa tarvittavien tietojen ja taitojen (3) että myös yleissivistyksen välittämisestä (5). Sen sijaan nykypäivän ihmiset odottavat enemmän persoonallisuuden kehittymistä tukevalta toiminnalta (4).

\section{Opinnollisuus jatkuvan koulutuksen rakennusaineena}

Tärkeimpinä osallistumistavoitteenaan kansalais- ja työväenopistoissa opiskelevat aikuiset pitävät itsensä kehittämistä, omien tietojen ja taitojen ylläpitämistä sekä mielekkään vapaa-ajan viettotavan saamista. He siis haluavat jatkuvan opiskelun avulla pysyä aktiivisina muuttuvassa yhteiskunnassa.

Fraasilta kuulostava vapaan sivistystyön periaate, pyrkimys kehittää kokonaispersoonallisuutta ja edistää kulttuuri- sekä yhteiskuntaelämään osallistumisessa tarvittavia valmiuksia, 


\section{Kuvio 1. Opiskelijoiden käsitykset opistojen kyvystä suoriutua tehtävistään.}

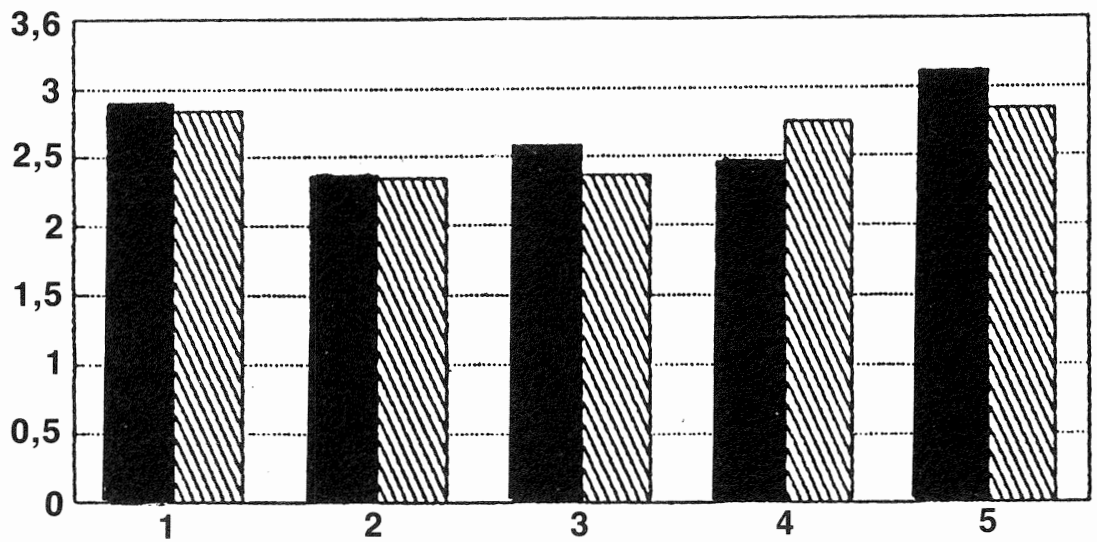

Lehtonen ja Tuomisto

$N=206$

\section{【IIIV Tämä aineisto}

$$
N=371
$$

ei ole pelkkää sanahelinää, vaan myös todellisuutta aikuisten elämänpyrkimyksissä.

Vapaan sivistystyön perinteinen opinnollisuus on säilyttänyt asemansa koulutuspolitiik. kamme ammatillisen aikuiskoulutuksen painotuksesta huolimatta. Opiskelu koetaan ke. hittävänä vapaa-ajan viettotapana ja mielekkäänä vastapainona arjen rutiineille. Kokemis. saan vaikutuksissa opiskelijat korostavat opiskelun harrastus- ja toimintamerkityksen ohella oppimistavoitteisia vaikutuksia, henkistä avar. tumista. Se, että opiskelijat olivat kokeneet opiskelun myönteisesti ja se, että heidän minäkuvansa näytti parantuneen, luo hyvää maaperää jatkuvan koulutuksen toteutumiselle.

Jos hyväksymme vaikuttavuuden määritelmäksi asetettujen tavoitteiden saavuttamisen ja jos pidämme vapaan sivistystyön keskeisimpinä tavoitteina opiskelijoiden itsensä asettamia tavoitteita, tämän tutkimuksen perusteella voimme todeta, että opistotoiminta on yhä edelleen vaikuttavaa.

\section{LÄHTEET}

Alanen, A. 1969. Edistävä ja viihdyttävä opintokerhotoiminta. Acta Universitatis Tamperensis, A 29. Tampere: Tampereen yliopisto.

Alanen, A. 1985. Johdatus aikuiskasvatukseen. Helsinki: Yleisradio.

Bock, L. K. 1980. Participation. Teoksessa A. B. Knox et al. (toim.) Developing, administering and evaluating adult education. San Francisco: Jossey Bass.

Boshier, R. W. 1982. Education Participation Scale, F-form. Vancouver: Learningspress.

Boshier, R. W. \& Collins, J. B. 1985. The Houle typology after twenty-two years: a large scale empirical test. Adult Education Quarterly 35 (3), $113-130$.

työväenopistossa. Jyväskylän yliopisto. Kasvatustieteen laitos. Proseminaarityö. (julkaisematon)

Lehtonen, H. \& Tuomisto, J. 1972. Aikuiskoulutukseen osallistuminen. Teoreettinen prosessimalli. Tampereen yliopisto. Aikuiskasvatuksen laitos. Tutkimuksia ja selvityksiä 1 .

Lehtonen, H. \& Tuomisto, J. 1973. Kansalaisopisto organisaationa. Tampereen yliopisto. Aikuiskasvatuksen laitos. Tutkimuksia ja selvityksiä 3 .

Vaherva, T. 1983. Koulutuksen vaikuttavuus. Käsiteanalyyttistä tarkastelua ja viitekehyksen hahmottelua. Jyväskylän yliopisto. Kasvatustieteen laitos. Julkaisu A 1.

Virolainen, S. 1991. Opiskelun tavoitteet ja koetut vaikutukset kansalais- ja työväenopistoissa. Jyväskylän yliopisto. Kasvatustieteen laitos. Pro gradu -tutkieima. (julkaisematon) 